\title{
Traços que deixam traços: arquivos pessoais no tempo presente
}

Traces that leave traces: personal archives and present time

Huellas que dejan huella: los archivos personales en la actualidad

\section{Organização}

Maria Teresa Santos Cunha

Universidade do Estado de Santa Catarina (Brasil)

http://orcid.org/0000-0001-6200-6713

http://lattes.cnpq.br/1895532605964830

mariatsc@gmail.com

Doris Bittencourt Almeida

Universidade Federal do Rio Grande do Sul (Brasil)

http://orcid.org/0000-0002-4817-0717

http://lattes.cnpq.br/5715085520250456

almeida.doris@gmail.com

\section{Apresentação}

Este Dossiê Temático reúne e problematiza a tarefa de organização, preservação e, concomitantemente, da utilização dos materiais de arquivos pessoais levadas a termo, pelos pesquisadores/historiadores da área, tanto por instituições custodiadoras nacionais e/ou internacionais como por pessoas comuns. As pesquisas identificam-se com os pressupostos teóricos da História do Tempo Presente ao considerar os arquivos pessoais nos diferentes estratos de tempo que os compõem e por analisar os documentos/acontecimentos que registram como testemunhos, em temporalidades distintas. Os arquivos pessoais guardam materiais e documentos em variados suportes que comportam traços sobre a história do indivíduo e, ao mesmo tempo, das redes em que se inscreve, ou seja, permitem identificar outros atores sociais e as interrelações estabelecidas no fazer-se desses sujeitos. Sua importância se configura como um modo privilegiado de acesso a vestígios e traços de sensibilidades, de encenação de atos rituais, de reconhecimento de diferentes práticas de sociabilidades geracionais dadas a ver através de uma produção discursiva de um determinado tempo e lugar. Por fim, reforça-se a relevância desses documentos/materiais produzidos no âmbito privado que, se recolhidos, organizados e socializados podem ampliar o horizonte de possibilidades em torno desses arquivos ao se 
constituírem como documentos/fontes para a pesquisa no campo do Patrimônio HistóricoEducativo, da História da Educação e da própria História no Tempo Presente.

Os sete textos que compõem este dossiê foram produzidos por autores nacionais e internacionais (Espanha e Itália) e são dotados de riqueza documental e analítica, problematizam de diferentes modos documentos pessoais, preservados na intimidade, cuidados e alimentados pelos seus titulares e, aqui, vêm a público, sendo apresentados e tramados nas narrativas produzidas pelos autores.

Assim, tem-se quatro artigos que tematizam arquivos pessoais de professores, sendo três deles, professores que construíram suas trajetórias em universidades federais. Nadia Maria Weber Santos e Alexandre Veiga apresentam a experiência de curadoria do acervo de Sandra Jatahy Pesavento (UFRGS), que se encontra salvaguardado no Instituto Histórico e Geográfico do Rio Grande do Sul. Maria Teresa Santos Cunha e Dóris Bittencourt Almeida discutem, em paralelo, os arquivos pessoais dos professores Walter Piazza (UFSC) e Balduino Andreola (UFRGS), salvaguardados, respectivamente, pelo Instituto de Documentação e Investigação em Ciências Humanas/UDESC, em Florianópolis/SC, e pelo Arquivo Histórico da Faculdade de Educação/UFRGS.

Ainda tematizando conjuntos documentais pessoais de professores, integram o dossiê dois artigos, um deles, produzido por Libania Xavier e Michelle Robert, sobre o arquivo de um professor de História de cursinhos pré-universitários, Rubin Santos Leão de Aquino, no Rio de Janeiro. Entre outros aspectos, discutem aspectos da cultura profissional referente à docência em História. Em perspectiva internacional, o artigo dos pesquisadores italianos Alberto Barausse e Rossella Andreassi investiga memórias de Amalia Andreasi, professora e diretora de creches públicas e privadas na cidade de Bari, província do sul da Itália, durante o século XX. O historiador espanhol Antonio Castillo Gomez, por sua vez, trata de iniciativas recentes para salvaguardar a memória escrita das classes subalternas, a partir do que denomina "arquivos à margem. e, problematiza, em particular, o que tais "arquivos de escritas populares" significam no campo dos arquivos pessoais ou auto-arquivos. Entre Espanha e Rio de Janeiro o artigo de Pablo Alvarez Dominguez e Maria Celi Chaves Vasconcelos (UERJ) alcança arquivos pessoais e institucionais e contém imagens variadas sobre o momento de realização da primeira comunhão, ritual católico ao qual às meninas estavam submetidas por suas famílias.

Para além dos estudos sobre arquivos de professores, Vania Grim Thies apresenta um texto que analisa um conjunto documental peculiar. Trata-se de cadernos de uso não escolar que reúnem memórias familiares, representativas das vivências no meio rural, e foram preservados por uma mulher que teve pouco acesso à escola. Nesses cadernos, constam registros das vivências no meio rural.

A disponibilização desses artigos, no presente Dossiê, traz o desejo da ampliação do campo das pesquisas sobre e nos arquivos pessoais, pela presença de diversificadas abordagens historiográficas que articulam História da Educação e História do Tempo Presente. Boa leitura! 